\title{
Job Dissatisfaction and Labour Turnover: Evidence from Brazil *
}

\author{
Paulo Aguiar do Monte ${ }^{\dagger}$
}

Julho/2010

*The author is grateful to professor Tiago V. de V. Cavalcanti for his helpful suggestions. The usual disclaimer about any mistakes and analysis applies. The author also thanks the CAPES (Coordenação de Aperfeiçoamento de Pessoal de Nível Superior) Foundation for providing the Postdoctoral Fellowship that allowed this work.

${ }^{\dagger}$ Professor at the Federal University of Paraiba (UFPB) - Brazil. 


\title{
Job Dissatisfaction and Labour Turnover: Evidence from Brazil
}

\section{Resumo}

Este artigo investiga a relação entre insatisfação no emprego e a possível saída do emprego no mercado de trabalho brasileiro tendo como base os dados da Pesquisa Mensal de Emprego (2004-2009) que traz informações sobre o perfil dos trabalhadores e as características do emprego. Embora existam outros estudos e métodos estatísticos para mensurar a (in)satisfação no emprego, poucos são os estudos que se utilizam de variáveis comportamentais como proxy de satisfação. Dentre as razões para o seu uso destacam-se a maior facilidade de obtê-las e ao caráter menos subjetivo desta variáveis quando comparadas com as variáveis comumente utilizadas na literatura. É importante destacar também que não existem estudos acadmicos no mercado de trabalho brasileiro relacionando satisfação e mudança de emprego. Seguindo a metodologia adotada por Souza-Poza e Souza-Poza (2007), este artigo utiliza-se de várias técnicas econométricas (dentre as quais os modelos Probit Multinomial e Probit Ordenado) para determintar se a satisfação do trabalhador pode ser um bom preditor de uma futura saída do emprego. Os resultados obtidos são consistentes com os encontrados na literatura para os outros países. Em geral, eles mostram a importância da satisfação em uma futura mobilidade no mercado de trabalho, principalmente quando se refere a mudança de um emprego para outro. Por fim, este artigo fornece uma nova abordagem para analisar a satisfação no mercado de trabalho brasileiro, dado que ao fazer uso de variável comportamental acaba minimizando os possíveis efeitos associados a fatores psicológicos e subjetivos que afetam as respostas dos trabalhadorse sobre o seu nvel de (in)satisfação no emprego.

Palavras-Chave: Insatisfação. Trabalho. Mobilidade.

\begin{abstract}
This paper investigates the relationship between job dissatisfaction and labour turnover using data from the Monthly Employment Survey (2004-2009) from Brazil which, has detailed information on individual and job characteristics. Although there are many studies and methods for measuring job satisfaction, to our knowledge, there are few studies using behavioral variables to measure of job satisfaction. Thus, this paper propose an objective behavioral measure to serve a more easily measurable proxy for the more subjective variable of job satisfaction. Moreover, there is no study on the Brazilian labor market that addresses the relationship between job satisfaction and labour turnover. Following the methodology adopted by Souza-Poza and Souza-Poza (2007), this paper used various econometric techniques (such as Multinomial and Odered Probit models) to determinte wheter job satisfaction is a good predictor of future job quits. The results found were consistent with the findings in the literature for other countries. In general, they show the importance of job satisfaction on future mobility, mainly on job-to-job tunover. Therefore, this paper provides to open another way to analyse job satisfaction, since the measure used minimizes the subjective effects that are associated with psychological factors which may affect the response of the worker about their level of (dis)satisfaction.
\end{abstract}

keywords: Job Dissatisfaction. Labour. Turnover.

Classificaco JEL: J28. J63.

Área ANPEC: Área 12 - Economia do Trabalho. 


\section{Introduction}

In the past three decades, there has been a debate on achieving quality in work and on the importance of generating better jobs in the more developed countries of the world. As argued by Slaterry and Selvarajan (2005), more and better jobs should be a principal objective in the EUs vision for the future. It is widely assume that the permanence of the employment open to an individual tends to increase his/her productivity, which can stimulate economic development.

Despite the vast literature available recently, the relationship between job satisfaction and labour turnover is still an area of active research [see for instance, Sousa-Poza and Hennerger (2000), Stier and Lewin-Epstein (2003), Sweeney and McFarlin (2004), Green and Tsitsianis (2005), Davoine and Erhel (2006), Kaiser (2007), Lvy-Garboua et al. (2007) and Clark and Postel-Vinay (2008)]. In general, previous studies have shown: (i) a direct relationship between job satisfaction and turnover [Clark et al. (1998), Royalti (1998)]; (ii) women tend to be more satisfied at work than men [Bokemeier and Lacy (1986), Hodson (1989)]; (iii) no consensus on the relationship between job satisfaction and firm size [Drakopoulos and Theodossiou (1997); Lang and Johnson (1994)].

Spector (1997) defined job satisfaction as how people feel about their jobs and different aspects related to them. An organisation's enviroment have significant effects on its workers and some of those effects are reflected in how a worker feels about their job. According to Herzberg et al. (1993), the main reason why workers are dissatisfied at work relates to the environment within which they work. In contrast, workers satisfaction is correlated with activity properly developed and the recognition by the employer (by means of salary raises, bonuses, promotion and other forms of incentives). Due to other factors relating a worker's behavior (psychological factors), some of them decide to seek another job while others remain in the same job, which ends up not being good for the employer because he/she has employees unmotivated in their company.

These arguments reinforce the importance of job satisfaction for both employers and employees. According to Nguyen et al. (2007) the organizations must know how to motivate

their employees since the more satisfied employees are the more likely to make profit from lower job turnover and higher productivity.

Although it is difficult to measure job satisfaction given its subjectivity, researchers have shown that job satisfaction is a strong predictor of overall individual well-being (DiazSerrano and Vieira, 2005) and also a good predictor of intentions or decisions of employees to leave a job. Almost always, the measure used for job satisfaction is based on responses from workers through surveys. (Souza-Poza and Souza-Poza, 2007).

Clark (1997) has suggested that the study of the degree of job satisfaction can be an indicator of more importance than the usual adopted in the literature such as salary and length of occupation. The literature tends to relate job satisfaction, usually measured with indicators of subjective evaluation of working conditions, with the socioeconomic characteristics of individuals (Clark and Oswald, 1996). Nguyen et al. (2007) argue that there are several compelling reasons why economists should care about job satisfaction, one being that it is a strong predictor of a worker's behaviour/performance, and one of the three most important predictors of overall well-being.

All of these references cited have shown that a high level of job satisfaction is negatively correlated with job turnover. Appelbaum et al. (2003) found that intention to leave a job is strongly correlated with low job satisfaction. Because each worker has his/her innate and acquired characteristics, it is natural that job satisfaction is also related to individual 
personality and profession, and moreover that the degree of satisfaction tends to change with the profile of the worker and the activity.

In the Brazilian labour market, there are few studies about the relationship between job turnover and job satisfaction. This might be due to the lack of reliable data on job satisfaction and the labour market. The only paper that we know about this topic for Brazil (Fontes and Machado, 2008) analyses the difference in job satisfaction between gender, age and occupation. This paper shows, for instance, that men are more likely to be dissatisfied with their occupation than women in Brazil.

The purpose of this paper is to investigate further data regarding job satisfaction from Brazil. Unlike previous studies (Fontes and Machado, 2008), this paper investigate the effect of job dissatisfaction on labour turnover using proxies for (dis)satisfaction in the labour market. In this case, we assume that seeking another job is an indicator of employee dissatisfaction, despite knowing that not all individuals who are dissatisfied in their jobs will seek another job; which can lead either to underestimation or overestimation in results.

The use of proxies for "dissatisfaction" may contain flaws, but is the most convenient in this case given the lack of direct observation. In addition, another advantage of this approach is that by analysing the behaviour of the worker who is seeking for a new job (a proxy for satisfaction), it is possible to minimize the bias of subjectivity (psychological factors) associated with their opinion of job satisfaction.

Freeman (1978) argues that job satisfaction is influenced by both subjective and objective factors. According to Freeman (1978, p. 1) the neglect of job satisfaction reflects professional suspicion of what may be called subjective variables: variables that measure what people say rather than what people do."

The dataset used is based on the Monthly Employment Survey, for six years (2004 to 2009). We use current job satisfaction to predict future mobility. We also control for other variables such as socio-demographic and job characteristics. Furthermore, it is important make it clear that there are no databases available about workers' response to job (dis)satisfaction.

This paper is organised as follows. Section 2 presents a review of the literature related to job satisfaction. Section 3 describes the methodological approach and dataset. Section 4 presents the descriptive analysis, and Section 5 describes the determinants of job satisfaction and labour turnover. Finally, Section 6 contains the concluding remarks.

\section{Labour Satisfaction on Literature: A Review}

Labour mobility and workers' satisfaction have been related in the literature. Spector (1997) defines job satisfaction as an affective response by an employee concerning his/her job.

Freeman (1978) is one of the seminal papers about this topic. Freeman (1978) shows that the probability of a worker's voluntarily leaves the job decreases with job satisfaction, although affirms that the workers also lead to complexities due to their dependency on psychological states. In turn, Hamermesh (1997) constructed a theory of overall job satisfaction.

These psychological states can be varied by different workers or occupations. Clark (1997) and Souza-Poza and Souza-Poza (2007) considered differences in job satisfaction by gender. Theodossiou and Zangelidis (2009) showed that job satisfaction is significantly higher for workers who have more tenure on the job. Shields and Price (2002) address the issue of the effects of race and racial harassment. Sloane and Williams (2000) and Nguyen 
et al. (2007) showed the importance of relative pay to determining job satisfaction. Allen and Van der Velden (2001) analysed the effects of educational mismatch.

The literature about labour market dynamics, especially on job quits, emphasized the importance of factors such as salary and expected wages to worker mobility. A variety of conceptual models for the turnover process have been developed during last thirty years. Clark (2001) affirms that mobility would only occur if the present discounted value of revenue associated with a choice of job was greater than the salary of the current job. This analysis is based on the neoclassical assumption of utility maximization by workers in a market with perfect information.

According to Fasang et al. (2007) job satisfaction may be based on two fundamental factors: professional aspirations (expected subjective) and opportunity (objective). In essence, job satisfaction is strongly depends on the availability of information about the current employment and the future opportunities available. Also Simon (1982) asserts that, the ability to make fully rational decisions is limited by two main factors: uncertainty (future) and the high price of the acquisition of information (present). Consequently, people are unable to maximize their usefulness in a purely rational sense. Thus, they follow a strategy of satisfaction, based on the aspiration that the satisfactory level is reached. In short, an employee is expected to change jobs when he or she is dissatisfied as a result of the real situation differing sufficiently from that desire, leading to job dissatisfaction, which, together with the possibility of change and information on the new job, trigger occupational change. However concrete this prediction may seem, it is practically impossible to measure it in a labour market which is highly dynamic and uncertain. For instance, Delfgaauw (2007) argues that its relevance is based on assumption that dissatisfied workers are more likely to search a new job than satisfied workers. The autor points out three main reasons that workers may leave their current job and search for a new one: (i) disconfort with an organisations specific job domain, like management; (ii) availability of a new job opportunity which yields higher expected utility than the current job; (iii) a feeling that some aspects of their current job can be improved upon.

Although there already exists a substantial body of literature which reports that job satisfaction is negatively associated with turnover intention, the interest in this theme continues to increase because there are several outcomes that may be generated by job satisfaction. Following this line, Mathieu and Zajac (1990) and Horn and Griffith (1995) argue that organizational commitments are negatively correlated with intention to quit, which, in turn is correlated with job satisfaction. And, Delfgaauw (2007) affirms that for some job domains, the conditions may vary sufficiently across jobs within an organization to make an internal job change a viable option.

Therefore, job satisfaction in the labour market should be seen as an important variable for understanding the dynamics of employment. The more knowledge we have about job satisfaction, more we understand the issue of productivity and turnover.

The importance of studying the dynamics of the labour market, especially the job quits, is based on the fact that workers who stay longer on one job position, the employee acquire more experience and skills in performing their tasks, achieving greater productivity. But if this individual leaves his employment, the company will have to hire a substitute, paying at least the costs of hiring and training, and possibly seeing declines in productivity. 


\section{Data and Methodology}

We use the Monthly Employment Survey (PME) from 2004 to 2009, which was collected by the Brazilian Institute of Geography and Statistics (IBGE). The PME provides a representative sample of the labour market above age 10 and covers six metropolitan regions of Brazil (1 - Recife, 2 - Salvador, 3 - Belo Horizonte, 4 - Rio de Janeiro, 5 - São Paulo and 6 - Porto Alegre). The form of data collection followed a rotation scheme and a monthly household panel structure, where each panel was surveyed for 4 consecutive months, then removed from the sample by 8 months, and returned again for another 4 months, then permanently excluded. In the PME the panels are refreshed every two years.

For this reason, between the first and last interview, the longitudinal period of each home could be up to 16 months if all the interviews had been successful. Based on household identification code we can follow individuals through the period. In order to minimize losses in the sample, we built a database consisting of only two interviews of all workers: first interview, $t=1$ (2004, 2006 or 2008), and, second interview, $t=2$ (2005, 2007 or 2009). Thus, we considered only two observations for each worker, one in each year, with an interval of 12 months between each interview. Therefore, any given worker, according to our methodology, will be present in only two years. Hence, the years 2004-2005, 2006-2007 and 2008-2009 form three distinct and independent samples which we will refer to as: sample 1 (2004-2005), sample 2 (2006-2007) and sample 3 (2008-2009) ${ }^{1}$.

The variables included in our study were chosen based on those that previous work has shown to be most relevant to determining job satisfaction. These are: gender (dummy variable, male or female), age [depending on the equation, can be either a continuous variable measuring the respondents age in years or a dummy variable)], marital status (dummy variable, which assume value 1 if is married, and 0 if not), have children (dummy variable which assume value 1 if have children less than 11 years, and 0 if not), schooling [depending on the equation, we use different measures either can be a dummy variables (low - less than 2 years of schooling - or high - more than 11 years of schooling) or a number of years of schooling], private sector (dummy variable), hourly wage rate (continuous variable) ${ }^{2}$, partition job (dummy variable which assumes value 1 if is a temporary job, and 0 if not), tenure (continuous variable measuring the respondents time of employment in his/her present main job) and region (dummy variable for each region).

As argued by Dilworth (2004) family issues can interfere in job satisfaction. Thus, the marital status and have children variables were included in the model as well the region variable which was included in order to capture the regional effects that exist, given the territorial dimension of the country that reflects the different characteristics of the labour market.

This analysis is restricted to workers who had a job in their first interview, aged 18-65 and who were followed the next year (second year). At the end of the follow-up, one part of the subjects were still employed on the same job, another part became unemployed but active job-seekers and the third part became economically inactive (out of labour force). Self-employed workers, employers and retired workers were not included.

\footnotetext{
${ }^{1}$ There are two important additional information to justify the this choice of which years to study: 1 . Since 2003 the questionnaire of the Monthly Employment Survey (PME) has been completely revamped, as part of its methodology. This is the reason why we consider the analysis from the year 2004. 2. Since the three samples are independent they could give give us a strong support to the findings.

${ }^{2}$ Hourly wage rate is in Real (Brazilian currency) $\mathrm{R} \$$. This variable was calculated by dividing the usual weekly gross pay by the usual weekly hours.
} 


\subsection{Job satisfaction measure}

As said earlier, previous literature emphasizes that job dissatisfaction can be a strong incentive to seek alternative opportunities. However, there are other external factors including macroeconomic factors and personal traits of the employee (job seeker behaviour) that also affect the decision to look for a new job. For instance, Lee and Mitchell (1994) proposed that not only job dissatisfaction causes the process of job turnover but also the subjective expected utility of the other opportunities.

There are models of turnover that describe job change due to new employment opportunities that lead to better satisfaction. March and Simon (1958) argued that voluntary employee departure results from two main factors. The first one is the perception about ease of movement from job to job that has evolved to mean perceived job alternatives. The second one is the desirability of movement that has evolved to mean job satisfaction. It is also supported in the work of Mobley (1977) that argues that staff turnover results from a particular combination of job dissatisfaction and perceived job alternatives.

Our variable to measure job dissatisfaction is actually a variable on-the-job search intensity of those people who were currently employed. This condition (being employed) is what gives us scope for attributing the concept of relative dissatisfaction ${ }^{3}$. Every worker in this condition can decide whether to look for a new job or not. We assume that each employed worker is able to determine his own level of job satisfaction. Thus, even considering that their level of satisfaction is high, the employee may seek a new job because he expects to further increase the level of job satisfaction. Hence, the demand for new job may not be directly related to job dissatisfaction in current position but the expectation of achieving a higher expected utility (job satisfaction) with a new employment.

In this context, the measure of job dissatisfaction adopted is based on-the-job search behaviour of employed workers and it depends on the intensity of the search which can assume different levels of dissatisfaction. The proxy variable used to measure the degree of the job dissatisfaction (relative dissatisfaction) is the intensity of seeking for another job. Therefore, the measure of job dissatisfaction is composed by four item instruments: 0 , for workers who were not seeking employment; 1 , for workers who were seeking employment on the current week; 2, for workers who were seeking employment on the current month; and 3 , for workers who were seeking employment on the current year ${ }^{4}$.

Although this criterion still has not been used in the literature, we adopted the idea from Slaterry and Selvarajan (2005). In their research, workers were asked to rate their chances of quitting a job as a temporary associate within different months of their employment. However, in our study, the information about job satisfaction is obtained via proxy variable that describes the behaviour of the employees and not just their perceptions. Although our measures for job dissatisfaction are certainly imperfect, we have several reasons to trust in it. First, it reflects the same kind of analysis that the typical variables used to capture job dissatisfaction. Second, we can reduce the subjectivity inherent in many variables used to measure job dissatisfaction, since we are capturing what workers did and not what workers said or thought.

\footnotetext{
${ }^{3}$ The Theory of On-The-Job Search explains the behaviour of employed individuals who search for a better job while others do not. For more details see Lambert (1991) and Allen and Van Der Velden (2001).

${ }^{4}$ As said earlier, not all dissatisfied workers seek new employment. According to Herzberg (1987) the opposite of job satisfaction is not job dissatisfaction but, rather, no job satisfaction; and similarly, the opposite of job dissatisfaction is not job satisfaction, but no job dissatisfaction.
} 


\section{Descriptive Analysis}

In this section, we present the summary statistics of the key variables used in this article. Data are from 32,151 workers (9,452 from the 1st sample, 10,924 from the 2nd sample and 11,776 from the 3rd sample) from Brazil. Table 1 shows the summary statistics describing the mean and standard deviation (in parentheses) of all variables used. Column 1 reports the variables, and the other columns report the different samples used in this study. Our samples consist of employed workers aged 18-65. We dropped self-employed workers, employers, retired workers and missing values.

Table 1: Summary Statistics: Sample Average and Sample Standard Deviation. 2004-2009

\begin{tabular}{l|cc|cc|cc}
\hline \hline \multirow{2}{*}{ Variables / Year } & \multicolumn{2}{|c|}{ (1st Sample) } & \multicolumn{2}{c}{ (2nd Sample) } & \multicolumn{2}{c}{ (3rd Sample) } \\
\cline { 2 - 7 } & 2004 & 2005 & 2006 & 2007 & 2008 & 2009 \\
\hline \hline Job Dissatisfaction & 0.029 & 0.040 & 0.029 & 0.044 & 0.044 & 0.044 \\
Male & $(0.168)$ & $(0.197)$ & $(0.168)$ & $(0.206)$ & $(0.206)$ & $(0.205)$ \\
Age (18 to 24 years) & 0.797 & 0.797 & 0.784 & 0.784 & 0.784 & 0.776 \\
& $(0.402)$ & $(0.402)$ & $(0.411)$ & $(0.411)$ & $(0.411)$ & $(0.417)$ \\
Age (50 to 65 years) & 0.035 & 0.024 & 0.037 & 0.025 & 0.025 & 0.020 \\
Married & $(0.184)$ & $(0.154)$ & $(0.188)$ & $(0.156)$ & $(0.156)$ & $(0.141)$ \\
Have children & 0.158 & 0.185 & 0.174 & 0.201 & 0.201 & 0.236 \\
Low schooling (<2 years) & $(0.364)$ & $(0.388)$ & $(0.379)$ & $(0.401)$ & $(0.401)$ & $(0.425)$ \\
High schooling (>11 years) & 0.746 & 0.747 & 0.726 & 0.739 & 0.739 & 0.736 \\
Private sector & $(0.435)$ & $(0.435)$ & $(0.446)$ & $(0.439)$ & $(0.439)$ & $(0.441)$ \\
Temporary job & 0.622 & 0.579 & 0.540 & 0.502 & 0.502 & 0.480 \\
Hourly wage rate & $(0.828)$ & $(0.787)$ & $(0.763)$ & $(0.740)$ & $(0.740)$ & $(0.714)$ \\
Tenure (years) & 0.014 & 0.015 & 0.015 & 0.012 & 0.012 & 0.011 \\
& $(0.118)$ & $(0.122)$ & $(0.121)$ & $(0.108)$ & $(0.108)$ & $(0.105)$ \\
\hline Total (Obs.) & 0.528 & 0.534 & 0.567 & 0.574 & 0.574 & 0.605 \\
\hline \hline & $(0.499)$ & $(0.499)$ & $(0.496)$ & $(0.495)$ & $(0.495)$ & $(0.489)$ \\
& 0.779 & 0.703 & 0.781 & 0.711 & 0.711 & 0.700 \\
& $(0.415)$ & $(0.457)$ & $(0.414)$ & $(0.453)$ & $(0.453)$ & $(0.458)$ \\
& 0.006 & 0.007 & 0.007 & 0.009 & 0.009 & 0.007 \\
& $(0.079)$ & $(0.082)$ & $(0.082)$ & $(0.093)$ & $(0.093)$ & $(0.086)$ \\
& 30.70 & 33.65 & 35.33 & 38.35 & 38.35 & 44.41 \\
& $(42.13)$ & $(45.55)$ & $(49.26)$ & $(49.81)$ & $(49.81)$ & $(57.32)$ \\
& 3.688 & 3.807 & 3.673 & 3.786 & 3.786 & 3.757 \\
& $(0.685)$ & $(0.535)$ & $(0.688)$ & $(0.572)$ & $(0.572)$ & $(0.610)$ \\
\hline
\end{tabular}

Source: Monthly Employment Survey. Note: Standard deviations are presented in parentheses.

Our sample consists of workers 33 years old on average, most of them men (about 78 percent in all samples), who are married, who have a a high level of schooling and who work in the private sector (about 75 percent). Regarding hourly wage rate, we can observe that the wage rate rose during the period, as we move from the first sample (30.70) to the last sample (44.41).

We defined a dissatisfied worker as one who was employed but seeking another job. Based on this definition, it is possible to observe that among the odd-numbered years (first interview) and the even-numbered years (second interview) the percentage of dissatisfied workers remained constant (in average $2.80 \%$ and $4.30 \%$, respectively). The relative increase 
of dissatisfaction between the years of each sample suggests that the job dissatisfaction increases when a worker spent more time in the same employment. At first, this result seems to indicate that the more time a worker spent on the same job the more dissatisfied a worker will be. However, the previous studies have show that the more adapted to the environment of the workplace, the lower tends to seek for another job (dissatisfaction) which results coud be find in Herzberg et al. (1957) and Bender and Heywood (2006).

Table 2 provides another look at the data, describing the statistics of the sample considering $T_{0}$ the initial situation (first interview) where all workers were employed, and $T_{1}$ the final situation (second interview) where workers can be either employed (job stayers or job-to-job movers) or non-employment (job-to-non employment) ${ }^{5}$. Since our sample has a time lag of 1 year for each individual, it is possible to observe the dynamics in the labour market during this period. In order to construct this table we considered the characteristics of employees from the first interview, except those concerning the dynamics of employment that were observed after 12 months of the first interview.

Foremost, it is relevant to note that approximately $88.90 \%$ (89.65\% of the 1 st sample, $89.44 \%$ from the 2nd sample and $87.80 \%$ from the 3rd sample - these values are expressed in the last row of the table) of workers remained employed on the same job, $6.42 \%$ became unemployed and $3.58 \%$ became economically inactive of all samples. Based on workers who remained employed (stayers job) after 12 months of follow up (second interview), we can detect that the percentage of men, married workers, aged between 18 and 24 years, worked in the private sector and who receive a lower hourly wage rate is higher among those who changed jobs (job-to-job movers).

Still in Table 2, a more detailed analysis can be made by observing that the percentage of workers dissatisfied with their job. It can be noticed that the percentage of dissatisfied workers (in the first interview) who become unemployed is higher compared to those who remained employed or who have become economically inactive. This fact may indicate a positive relationship between job dissatisfaction and a future job turnover.

\footnotetext{
${ }^{5}$ According Royalti (1998) this division is important because the worker's behaviour may vary significantly between gender.
} 


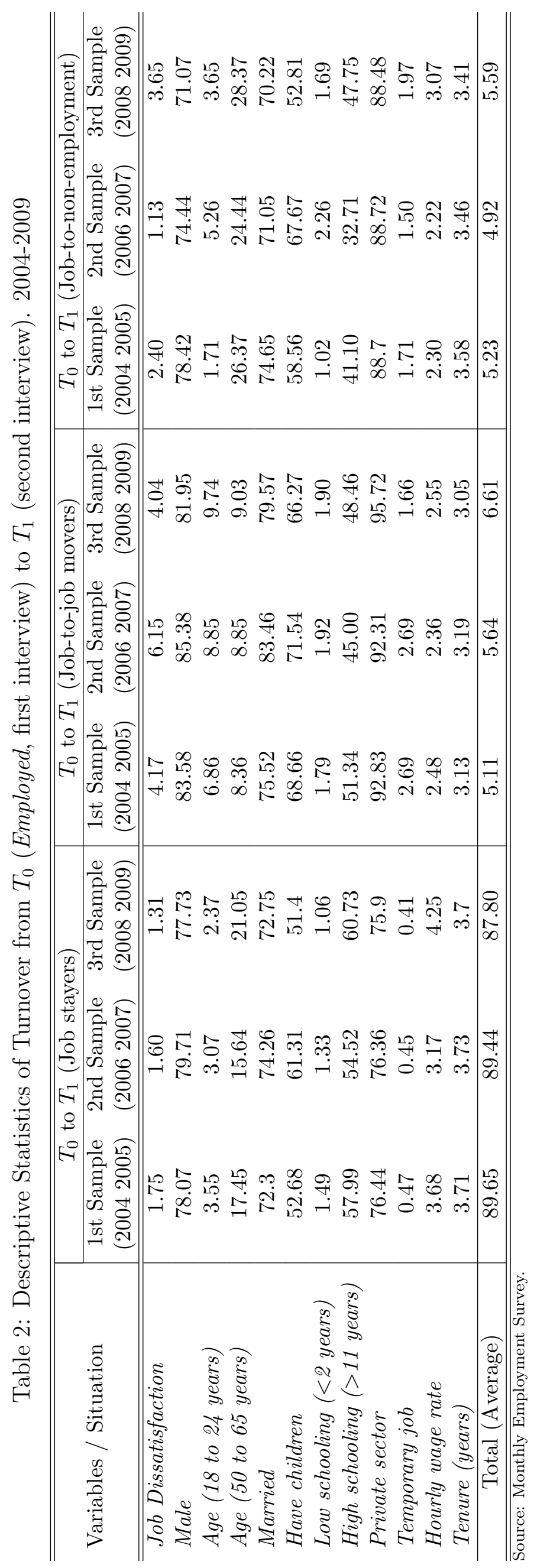




\section{Econometrics Results}

In this section we estimate the effects of job satisfaction on the dynamics of the labour market. There have been several models of labour turnover proposed in the last few years ${ }^{6}$. In most cases, job satisfaction is depicted as antecedents to turnover intention and econometric models seeking to observe the correlation of these variables.

First of all, we investigate the determinants of job satisfaction by probit model (Table 3). In this case, the dependent variable takes the value 1, for workers dissatisfied, and 0 , for workers satisfied. Recalling that we consider as workers dissatisfied those who were looking for a new job. It is important to emphasize that only workers who had a current job were considered in the sample. The control variables used are: gender, age, marital status, children, schooling, public sector, temporary job, hourly wage rate, tenure, industry sector and region 1-6.

Table 3 shows the results. In general, the estimation results were similar to those found in the literature, which reinforce the importance of variables such as age, level of schooling, temporary job, tenure, industry sector and region for determination of job dissatisfaction. The effect of age indicates that older workers tend to have a lower dissatisfaction. The same is true for those who receive higher wages, have more time of employment (tenure), and who have a higher level of schooling. The effect of age and tenure may be explained jointly by the trend of greater employment stability (job career) and, consequently, the lower necessity to seek another job (Herzberg et al., 1957; Lee and Wilbur, 1985). The fact that employees with a higher level of education had higher job satisfaction may be related to their greater stability in employment (Bender and Heywood, 2006). Regional variables were also included due to the different characteristics of the Brazilian labour market. Moreover, region 4 (Metropolitan Region of Rio de Janeiro), region 5 (Metropolitan Region of São Paulo) and region 6 (Metropolitan Region of Porto Alegre) are the first three most economically developed regions, showed highest levels of dissatisfaction when compared to the reference region (Metropolitan Region of Salvador), ceteris paribus.

\footnotetext{
${ }^{6}$ Horn and Griffeth (1995) and Maertz and Campion (1998) summarize various theoretical frameworks of labour turnover.
} 
Table 3: Probit model for Determinants of Job Dissatisfaction. 2004-2009

\begin{tabular}{|c|c|c|c|c|c|c|}
\hline \multirow{2}{*}{ Variables / Year } & \multicolumn{2}{|c|}{ 1st Sample } & \multicolumn{2}{|c|}{ 2nd Sample } & \multicolumn{2}{|c|}{ 3rd Sample } \\
\hline & 2004 & 2005 & 2006 & 2007 & 2008 & 2009 \\
\hline Male & -0.113 & 0.000 & -0.015 & $0.229^{* * *}$ & 0.052 & 0.030 \\
\hline Age (years) & $-0.018^{*}$ & $-0.016^{*}$ & $-0.016^{*}$ & $-0.022^{*}$ & $-0.020^{*}$ & $-0.013^{*}$ \\
\hline Married & 0.020 & -0.02 & -0.022 & -0.077 & -0.153 & $-0.249 * *$ \\
\hline Have children & $0.079 * * *$ & -0.083 & 0.049 & -0.032 & $-0.090 * * *$ & 0.079 \\
\hline Schooling (years) & $0.202^{*}$ & $0.143^{*}$ & $0.331^{*}$ & $0.096^{* *}$ & $0.243^{*}$ & $0.124^{* *}$ \\
\hline Private sector & 0.138 & 0.189 & 0.089 & $-0.245^{*}$ & 0.077 & -0.056 \\
\hline Temporary job & 0.524 & 0.453 & $0.583^{* *}$ & $0.510 * *$ & -0.062 & 0.026 \\
\hline Hourly wage rate & 0.000 & $-0.005^{* *}$ & $-0.002^{* * *}$ & $-0.003^{* *}$ & -0.001 & -0.001 \\
\hline Tenure (years) & $-0.245^{*}$ & $-0.298^{*}$ & $-0.171^{*}$ & $-0.355^{*}$ & $-0.157^{*}$ & $-0.335^{*}$ \\
\hline Industry sector & $-0.360^{*}$ & $-0.189 * * *$ & $-0.233^{* *}$ & $-0.261^{*}$ & $-0.240^{*}$ & -0.132 \\
\hline Region1 & $-0.448^{* *}$ & $-0.780^{*}$ & $-0.426^{*}$ & -0.155 & $-0.614^{*}$ & $-0.216^{*}$ \\
\hline Region3 & $-0.418^{*}$ & -0.215 & $-0.363^{*}$ & 0.051 & $-0.285^{* *}$ & $0.040^{*}$ \\
\hline Region4 & $-0.261^{*}$ & $-0.519^{*}$ & $-0.432^{*}$ & $-0.321^{*}$ & $-0.263^{* *}$ & $-0.285^{* *}$ \\
\hline Region5 & $-0.372^{*}$ & $-0.595^{*}$ & $-0.436^{*}$ & $-0.260 * * *$ & $-0.498^{*}$ & -0.193 \\
\hline Region6 & $-0.470^{*}$ & $-0.591^{*}$ & $-0.593^{*}$ & -0.222 & $-0.534^{*}$ & $-0.455^{*}$ \\
\hline Constant & $-0.905^{* *}$ & -0.394 & $-1.741^{*}$ & 0.215 & $-1.164^{*}$ & -0.400 \\
\hline Log-likelihood & -568.636 & -399.214 & -647.647 & -708.764 & -702.715 & -537.903 \\
\hline Total (Obs.) & 4,726 & 4,460 & 5,452 & 5,146 & 5,834 & 5,511 \\
\hline
\end{tabular}

Because the determinants of job dissatisfaction also can be measured on a scale from 0 (satisfied) to 3 (completely dissatisfied), we estimate an Ordered Probit model. Therefore, the dependent variable of the ordered probit model has four possible values: 0 , for satisfied, to 3, for most dissatisfied. The part of the survey on-the-job search started with the question: Did you seek another job in the reference period?. The reference period varies from week (more dissatisfied value 3), month (value 2) until year (value 1). If the worker didnt seek another job in some of mentioned periods, we considered that he/she is satisfied in his/her current job (value 0).

In this context, Table 4 gives the results of estimation by ordered probit. A comparison of the results found by this investigation and with previous results (see Table 3) reinforces the idea that job dissatisfaction tends to decrease with age, increase for temporary jobs and increase according to the schooling level of workers ${ }^{7}$. Moreover, job dissatisfaction tends to decline with the increase in wages, although the results were not very accurate since some parameters were insignificant. We also can observe that the male coefficients were significant and negative in all samples, indicating that, probably, there is gender difference. A similar result was observed in Royalty (1998), however differently from what was observed by Booth and Francesconi (1999) and Souza-Poza and Souza-Poza $(2007)^{8}$.The other two variables that were significant in all equations were schooling and employment duration (tenure). While the first one obtained a positive parameter, the second one showed the negative sign, indicating that the time spent in employment tends to lead to job dissatisfaction.

We also analysed the dynamics of labour market. For this, we defined stayers as workers who were at the same jobs in each sample (for example, the 1st sample) and movers as

\footnotetext{
${ }^{7}$ Davoine (2005) founds that the effect of education on job satisfaction is also country specific frameworks.

${ }^{8}$ In general, studies have highlighted that women tend to be more satisfied than men (Kaiser, 2002; Sloane and Williams, 2000]. Clark (1997) argue that womens higher job satisfaction is still a reflection of poor working conditions they had in the past, which means they have lower expectations of job satisfaction.
} 
Table 4: Ordered Probit model for Determinants of Job Dissatisfaction. 2004-2009

\begin{tabular}{l|cc|cc|cc}
\hline \hline \multirow{2}{*}{ Variables / Year } & \multicolumn{2}{|c|}{ 1st Sample } & \multicolumn{2}{|c|}{ 2nd Sample } & \multicolumn{2}{c}{ 3rd Sample } \\
\cline { 2 - 7 } & 2004 & 2005 & 2006 & 2007 & 2008 & 2009 \\
\hline \hline Male & -0.113 & -0.002 & -0.008 & $0.218^{* * *}$ & 0.069 & 0.008 \\
Age (years) & $-0.018^{*}$ & $-0.016^{*}$ & $-0.016^{*}$ & $-0.021^{*}$ & $-0.019^{*}$ & $-0.014^{*}$ \\
Married & 0.020 & -0.012 & -0.024 & -0.063 & $-0.159^{* * *}$ & $-0.244^{* *}$ \\
Have children & $0.079^{* *}$ & -0.084 & 0.049 & -0.033 & $-0.089^{* * *}$ & 0.076 \\
Schooling (years) & $0.202^{*}$ & $0.137^{* *}$ & $0.331^{*}$ & $0.096^{* *}$ & $0.241^{*}$ & $0.123^{* *}$ \\
Private sector & 0.138 & 0.175 & 0.082 & $-0.245^{*}$ & 0.068 & -0.054 \\
Temporary job & 0.524 & 0.438 & $0.572^{* *}$ & $0.534^{* *}$ & -0.039 & 0.065 \\
Hourly wage rate & 0.000 & $-0.005^{* *}$ & $-0.002^{* * *}$ & $-0.003^{* *}$ & -0.001 & -0.001 \\
Tenure (years) & $-0.245^{*}$ & $-0.307^{*}$ & $-0.160^{*}$ & $-0.365^{*}$ & $-0.168^{*}$ & $-0.333^{*}$ \\
Industry sector & $-0.360^{*}$ & $-0.191^{* * *}$ & $-0.223^{* *}$ & $-0.242^{*}$ & $-0.234^{*}$ & -0.135 \\
Region1 & $-0.448^{* *}$ & $-0.799^{*}$ & $-0.406^{*}$ & -0.163 & $-0.644^{*}$ & -0.216 \\
Region3 & $-0.418^{*}$ & $-0.238^{* * *}$ & $-0.354^{*}$ & 0.041 & $-0.304^{* *}$ & 0.008 \\
Region4 & $-0.261^{*}$ & $-0.503^{*}$ & $-0.396^{*}$ & $-0.302^{* *}$ & $-0.250^{*}$ & $-0.291^{* *}$ \\
Region5 & $-0.372^{*}$ & $-0.585^{*}$ & $-0.436^{*}$ & $-0.249^{* * *}$ & $-0.516^{*}$ & -0.215 \\
Region6 & $-0.470^{* *}$ & $-0.596^{*}$ & $-0.593^{*}$ & -0.214 & $-0.540^{*}$ & $-0.474^{*}$ \\
\hline Log-likelihood & -690.699 & -481.594 & -647.647 & -708.764 & -864.112 & -646.938 \\
\hline \multicolumn{1}{c}{ Total (Obs.) } & 4,726 & 4,460 & 5,452 & 5,146 & 5,834 & 5,511 \\
\hline
\end{tabular}

Source: Monthly Employment Survey.****, ${ }^{* *}, *$ indicate significant at the $10 \%, 5 \%$ and $1 \%$ confidence levels, respectively.

Note: Job dissatisfaction scores can take on 4 possible values ranging from 0 (satisfied) to 10 (completely dissatisfied).

workers who were job-to-job movers (workers who changed jobs, for example between 2004 and 2005), job-to-non-employment (workers who were unemployed during the second interview, for example in 2005) and job-to-inactivity (workers who were economically inactive during the second interview, for example in 2005). Our measure of job turnover is 1-year separation rates.

Based on monitoring over one year (interval of interviews), individuals who were employed in the first interview and left their jobs in the second interview were defined as movers. It is important to observe that as this question was only posed to employed individuals in the current year (second interview); hence, movers from employment to non-employment or inactivity were identified by comparing employment status in their first interview with that in their second interview.

First, we used the standard probit model to capture the separation decisions. In this case, the probit models dependent variable has two possible values: 0 , for stayers and, 1 for movers (movers included job-to-job movers, job-to-non-employment and job-to-inactivity). The results are show in Table 5 and indicate a clear positive correlation between job dissatisfaction and quits ${ }^{9}$. Thus, similar to other papers, the results point out that job satisfaction is a good predictor of job turnover, especially future quits.

Moreover, workers with a higher level of schooling are the ones least subject to change jobs (movers) and men are more likely to change their jobs than women. As a result of this last information seems that the effect of job satisfaction on labour turnover differs between men and women, where men are more likely to change over the situation in the labour market; differently from what was observed by Sloane and Williams (2000) and Souza-Poza and Souza-Poza (2007).

Regarding the other controls, we observe that: (1) the sign of the public sector variable

\footnotetext{
${ }^{9}$ Industry sector was excluded because of the high correlation with the variables included in the model.
} 
was negative, indicating that the relationship is indirect with the job dissatisfaction as observed by Green (2004). This result may be explained by the fact that in Brazil the public sector employees enjoy relative job security, which could also affect a public sector employees willingness to quit. In turn, the tenure variable is negatively related with the probability of changing jobs, as found by Campbell (1997); (2) the marital status had no effect on job satisfaction. In general, the literature does not show a strong relationship between these two. Some studies have indicated mixed results regarding marital status and job satisfaction (Bedelan et al., 1992; Lee and Wilbur, 1985), while others prefer to point the existence of a positive relationship even more in favour of married workers (Lambert, 1991; Kellough, 1990).

Table 5: Probit model for Job Separation and Job Dissatisfaction. 2004-2009

\begin{tabular}{|c|c|c|c|}
\hline \multirow{2}{*}{ Variables / Year } & 1st Sample & 2nd Sample & 3rd Sample \\
\hline & $(20042005)$ & $(20062007)$ & $(20082009)$ \\
\hline Job Dissatisfaction & $0.244^{*}$ & $0.119^{* *}$ & $0.240^{*}$ \\
\hline Male & 0.156 & $0.224^{* *}$ & 0.044 \\
\hline Age (18 to 24 years) & $0.553^{* *}$ & 0.228 & $0.391^{*}$ \\
\hline Age (50 to 65 years) & $-0.255^{* *}$ & $-0.189 * *$ & $-0.332^{*}$ \\
\hline Married & -0.015 & -0.078 & 0.059 \\
\hline Have children & -0.002 & 0.058 & $0.073^{* *}$ \\
\hline Low schooling (<2 years) & 0.107 & -0.293 & -0.307 \\
\hline High schooling (>11 years) & $-0.116^{* * *}$ & $-0.134^{* *}$ & $-0.191^{*}$ \\
\hline Industry & $0.274^{*}$ & 0.073 & 0.075 \\
\hline Private sector & $-0.177^{* *}$ & $-0.128 * * *$ & $-0.148^{* *}$ \\
\hline Temporary job & $1.491^{*}$ & $1.603^{*}$ & $1.450^{*}$ \\
\hline Tenure (years) & $-0.072^{*}$ & $-0.422^{*}$ & $-0.423^{*}$ \\
\hline Region1 & 0.007 & 0.081 & $0.303^{* * *}$ \\
\hline Region3 & -0.109 & 0.123 & $0.375^{*}$ \\
\hline Region4 & 0.027 & $-0.237^{* *}$ & -0.08 \\
\hline Region5 & 0.203 & 0.053 & 0.115 \\
\hline Region6 & -0.369 & 0.131 & $0.282^{* *}$ \\
\hline Constant & $-0.343^{* * *}$ & -0.077 & -0.053 \\
\hline Log-likelihood & -872.7411 & $-1,088.47$ & -1281.684 \\
\hline Total (Obs.) & 4,460 & 5,170 & 5,532 \\
\hline
\end{tabular}

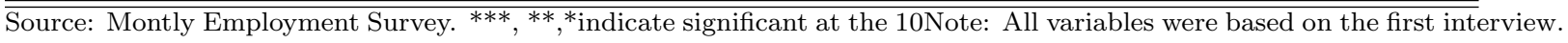
Only the situation in the labor market, i.e., the dependent variable (Job stayers $=0$; Job-to-job movers or Job-to-nonemployment movers $=1$ ) was based on the second interview. 
Following the methodology adopted by Royalti (1998) we apply the multionomial probit model to analyse job turnover dynamics during each interview. As in the previous estimation, our measure of job turnover is 1-year separation rates $\left(T_{0}\right.$ first interview - to $T_{1}$ second interview). However, in this estimation, the dependent variable has three possible values: 0 , for stayers; 1 , for job-to-job movers; 2 , for job-to-non-employment movers. The reference group remains the stayers.

Table 6 presents results for the multinomial estimation procedure. The first noticeable result is the significance of the coeficient of the job dissatisfaction variable. In all regressions of part I (job-to-job mobility) the coefficient of the job satisfaction is positive and and also statistically different from zero at 99 percent confidence level which suggests that job dissatisfaction has a strong influence on job-to-job mobility. In general, several variables proved to be good predictors of job to job turnover (such as dissatisfaction, age, schooling, private sector, tenure, and region).

The same analysis cannot be made with respect all regressions of part II (job-to-nonemployment), except the last estimation (3rd sample) with respect the variable job dissatisfied. Therefore, it seems that doesn't exist a strong relationship between job dissatisfaction and job-to-non-employment mobility. In turn, in this estimations, only variables of schooling, tenure and region were statistically different from zero at 95 percent confidence level, in different estimations.

A more detailed study for each of these variables could provide more accurate results, as observed by Royalti (1998) with respect to gender, where it was shown that the divergence in their turnover behaviour between women and men is due to the difference in the level of schooling between the genders. In respect to age and tenure, Herzberg et. al (1985), Clark (1997), Souza-Poza and Souza-Poza (2007) argue that there is a well-defined u-shape relationship. They found that job satisfaction tends to be high when people started their first job (even most young employees), but it subsequently declined until people reached their late twenties or early thirties, often because of limited opportunities for advancement, when it began to rise. According to Herzberg et. al (1985) increasing maturity and work experience led the employee to adjust theis wokr expectations to a more realistic level which tend to increase the level of job satisfacion.

These results seem to indicate that personal characteristics of the employees may lead them to change jobs, possibly to seek better employment opportunities (job-to-job turnover). The significance of the variables (dissatisfaction, gender, high schooling, tenure) is associated with higher levels of human capital of workers, which make them seek better employment conditions. According to Hezberg (1957) increasing maturity and work experience leads employees to adjust theirs ambitions and work expectations to a more realistic level which tends to raise their level of satisfaction. Hunt and Saul (1975) add that the there is an everdecreasing gap between employees' expectations and actual environmental returns, which results in increasing levels of job satisfaction.

In turn, the output of the status of job-to-non-employment seems to be a consequence of other factors (for example, the dynamics of the market labour), given that few variables were statistically insignificant, and only one (children) is directly correlated ${ }^{10}$.

\footnotetext{
${ }^{10}$ The literature has no consensus on having dependent children. Haile (2009) found that having dependent children (less than 7 years) is associated with four of the eight facet satisfaction measures. In contrast, the author observed that having dependents other than children is associated negatively with nearly all facet satisfaction measures.
} 


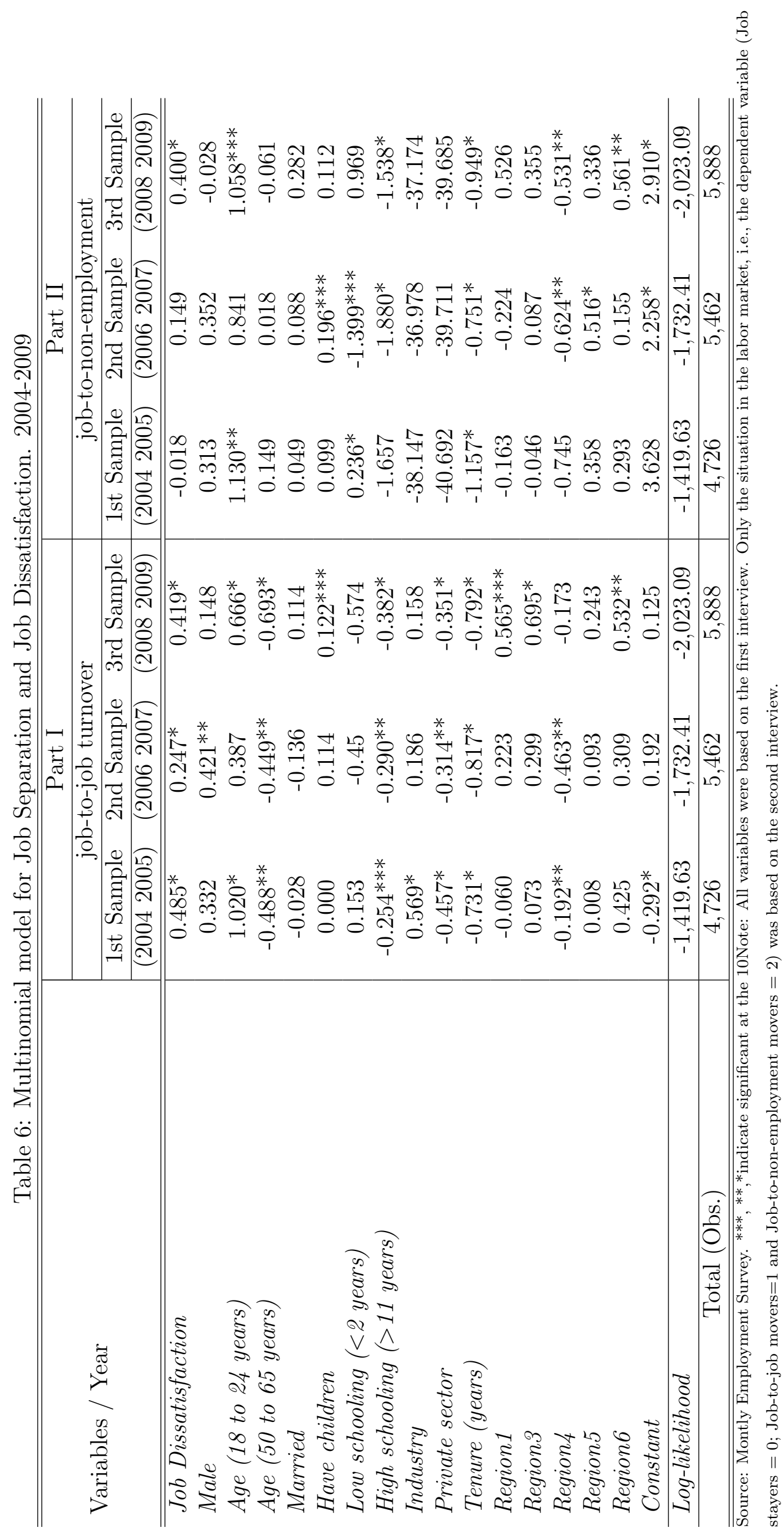




\section{Concluding Remarks}

Empirical evidence on the relationship between job satisfaction and labour turnover is still growing in the literature. Most of the case, the measure used for job satisfaction is derived directly through the responses from workers through surveys (Souza-Poza and Souza-Poza, 2001). Researchers use these data to determine the probability of job quits. In this study however, we try to minimize the possible effect of depending much on psychological states (cited by Freeman, 1978) in analyzing job satisfaction through proxy variables which were depicted in the behaviour of the individual seeking for a new job. The measure adopted was actually a variable on-the-job search intensity of those workers who were currently employed. Thus, we assume that the demand for new job may not be directly related to job dissatisfaction in current position but the expectation of achieving a higher expected utility (job satisfaction) with a new employment, which give us scope for attributing the concept of relative dissatisfaction.

Through the data collected by Monthly Employment Survey (2004-2009) from Brazil, one of this papers main research questions was to determine the causes of job dissatisfaction and its relationship with labour turnover. Using standard Probit and Ordered Probit models, we showed that the effect of job dissatisfaction on labour turnover differs as a function of gender, age, level of schooling, type of employment contract and tenure. The impact of certain variables like gender and age is still inconsistent, as some studies (Britton, 1997) that found that women have lower job satisfaction than men whilst in others men have lower job satisfaction (Lambert et al., 2001). The same is true with respect to age, where there exists evidence that suggests a U-shaped relationship between age and job satisfaction (Sloane and Ward, 2001) although there is also some evidence that satisfaction increases with age (Lee and Wilbur, 1985; Shields and Price, 2002). Moreover, the results indicate that the variable tenure is a good predictor in determining job dissatisfaction and, in general, the more time the worker spent on the same job, the lower is the probability to seek for another job (dissatisfaction).

Furthermore, using a multinomial probit model, we observed that job-to-job mobility is affected by level of job satisfaction while job-to-non-employment is not, suggesting that the personal characteristics of the employees may lead them to change jobs or possibly to seek better employment opportunities (job-to-job turnover). However, the output to job-to-nonemployment seems to be a consequence of other factors, for example, the dynamics of the market labour.

Finally, for the most part, the results confirmed the theoretical framework used and agreed with previous studies about this topic. However, the most important result we found was that variables related to workers' behaviour can be used as a proxy for dissatisfaction. In our case, we used variables related to the intensity on-the-job-search for those workers who were employed. The results found support for the findings in the literature and contribute to the opening of another way to analyse job satisfaction, minimizing the subjective effects that are associated with psychological factors of which may affect the response of the worker about their level of satisfaction. However, it is important to clarify that the relationships studied are considerably influenced by the particular satisfaction criterion involved and the type of sample. 


\section{References}

[1] Allen, J., Van Der Velden, R., 2001. Educational mismatches versus skill mismatches: effects on wages, job satisfaction, and on-the-job search. Oxford Economic Papers, 53, 434-452.

[2] Appelbaum, E., Berg, P, Frost, A., Preuss, G., 2003. The effects of restructuring on low-wage, low-skilled workers in U.S. Hospital. In Appelbaum, E., Bernhardt, A., Murnane, R. (Eds.) Low-Wage America: How employers are reshaping opportunity in the workplace. New York: Russel Sage Foundation.

[3] Bedelan, A. G., Ferris, G. R., Kacmar, K. M., 1992. Age, tenure, and job satisfaction: A tale of two perspectives. Journal of Vocational Behavior, 40(1), 33-48.

[4] Bender, K. A., Heywood, J. S., 2006. Job Satisfaction of the Highly Educated: The Role of Gender, Academic Tenure, and Comparison Income. Scottish Journal of Political Economy.

[5] Campbell, C.M., 1997. The determinants of dismissals, quits, and layoffs: a multinomial logit approach. Southern Economic Journal, 63, 1066-1073.

[6] Clark, A.E., 1997. Job satisfaction and gender: why are women so happy at work? Labour Economics, 4, 341-372.

[7] Clark, A.E., 2001. What really matters in a job? Hedonic measurement using quit data. Labour Economics, 8, 223-242.

[8] Clark, A.E., Oswald, A.J., 1996. Satisfaction and comparison income. Journal of Public Economics, 61, 359-381.

[9] Clark, A.E., Postel-Vinay, F., 2008. Job security and job protection. Oxford Economic Papers, in press.

[10] Clark, A.E., Georgellis, Y., Sanfey, P., 1998. Job Satisfaction. Wage changes and quits: Evidence from Germany. Research in Labour Economics, 17, 95-122.

[11] Davoine, L., Erhel, C., 2006. La Qualite de lEmploi: une perspective europe enne. La qualite de lemploi, La decouverte, Paris.

[12] Davoine, L. 2005. Les determinants de la satisfaction au travail en Europe:Limportance du contexte.Working paper.

[13] Delfgaauw, J., 2007. The effect of job satisfaction on job search: Not just whether, but also where. Labour Economics, Elsevier, 14(3), 299-317.

[14] Diaz-Serrano, L., Vieira, J.A.C., 2005. Low pay, higher pay and job satisfaction within the European Union: empirical evidence from fourteen countries. IZA. DP, 1558.

[15] Dilworth, J.E.L., 2004. Predictors of negative spillover from family to work. Journal of Family Issues, 25, 241-261.

[16] Drakopoulos, S.A., Theodossiou, I., 1997. Job satisfaction and target earning. Journal of Economic Psychology, 18, 693704.

[17] Fasang, A., Geerdes, S., Schomann, K., Siarov, L., 2007. Job satisfaction and labour market mobility. In European Foundation for the Improvement of Living and Working Conditions. 
[18] Fontes, A., Machado, D.C., 2008. Uma medida do grau de satisfao no trabalho: um estudo para homens e Mulheres. Anais do XVI Encontro Nacional de Estudos Populacionais. Caxambu, MG.

[19] Freeman, R.B., 1978. Job satisfaction as an economic variable. American Economic Review, 68, 135-141.

[20] Green, F., 2004. Work intensification, discretion, and the decline in well-being at work. Eastern Economic Journal, 30, 615-625.

[21] Green, F., Tsitsianis, N., 2005. An investigation of national trends in job satisfaction in Britain and Germany. British Journal of Industrial Relations, 43, 401-430.

[22] Hamermesh, D.S., 1977. Economic aspects of job satisfaction. In: Ashenfelter, O., Oates, W.E. (Eds.), Essays in Labour Market Analysis. Wiley, New York, 53-72.

[23] Haile, G.A., 2009. Workplace Job Satisfaction in Britain: Evidence from Linked Employer-Employee Data. IZA DP n. 4101.

[24] Herzberg, F., Mausner, B., Snyderman, B. B., 1993. The motivation to work. Transaction Publishers. New Brunswick, N.J., U.S.A.

[25] Herzberg, F., Mausner, B., Peterson, R. 0., Capwell, D. F., 1975. Job Attitudes: Review of Research and Opinion. Pittsburgh: Psychological Service of Pittsburgh.

[26] Herzberg, F., 1987. One more time: How do you motivate employees? Harvard Business Review SeptemberOctober, 109-120.

[27] Horn, P.W., Griffeth, R.W., 1995. Employee turnover. Cincinnati, OH: South-Western.

[28] Hunt, J. W., Saul, P. N., 1975. The Relationship of Age, Tenure, and Job Satisfaction in Males and Females. The Academy of Management Journal, 18, No. 4, 690-702.

[29] Kaiser, L. C., 2007. Gender-Job satisfaction differences across Europe: an indicator for labour market modernization. International Journal of Manpower, 28, 75-94.

[30] Kaiser, L. C., 2002. Job satisfaction: A Comparison of Standard, Non Standard, and Self-Employment Patterns across Europe with a Special note to the Gender/Job satisfaction paradox. EPAG Working Paper 27.

[31] Kellough, E. 1990. Integration in the public workplace: Determinants of minority and female employment in federal agencies. Public Administration Review, 53, 189-202.

[32] Lambert, S. J., 1991. The combined effects of job and family characteristics on the job satisfaction, job involvement, and intrinsic motivations of men and women workers. Journal of Organizational Behavior, 12, 341-363.

[33] Lang, J.R., Johnson, N.B., 1994. Job satisfaction and firm size: an interactionist perspective. The Journal of Socio-Economics, 23, 405-423.

[34] Lee, T. W., Mitchell, T. R., 1994. An alternative approach: The unfolding model of employee turnover. Academy of Management Review, 19: 51-89.

[35] Lee, R., Wilbur, E. R., 1985. Age, education, job tenure, salary, job characteristics, and job satisfaction: A multivariate analysis. Human Relations, 38, 781-791. 
[36] Lvy-Garboua, L., Montmarquette, C., Simonnnet, V., 2007. Job satisfaction and quits. Labour Economics, 14, 251-268.

[37] Maertz, C. P., Campion, M.A., 1998. 25 years of voluntary turnover research: A review and critique. In C. L. Cooper and I. T. Robertson (Eds.). International Review of Industrial and Organizational psychology. New York. Wiley.

[38] March, J. G., Simon, H. A., 1958. Organizations. New York: Wiley. Mobley, W. H. 1977. Intermediate linkages in the relationship between job satisfaction and employee turnover. Journal of Applied Psychology, 62: 237-240.

[39] Mathieu, J. E., Zajac, D.M., 1990. A review and meta-analysis of the antecedents, correlates, and consequences of organizational commitment. Psychological Bulletin, 108, 171-194.

[40] Mobley, W. H., 1977. Intermediate linkages in the relationship between job satisfaction and employee turnover. Journal of Applied Psychology, 62: 237-240.

[41] Nguyen, A, Taylor, J., Bradley, S., 2007. Relative pay and job satisfaction: some new evidence. Development and Policies Research Center. MPRA, n 1382.

[42] Royalty, A.B., 1998. Job-to-job and job-to-non-employment turnover by gender and education level. Journal of Labor Economics 16, 392-443.

[43] Shields, M., Price, S., 2002. Racial harassment, job satisfaction and intentions to quit: Evidence from British Nursing profession. Economica, 69, 295-362.

[44] Simon, H.A., 1982. Models of bounded rationality. Cambridge, MIT Press.

[45] Sloane, P. J., Ward, M. E., 2001. Cohort effects and job satisfaction of academics. Applied Economics Letters, 8, 787-791.

[46] Sloane, P.J., Williams, H., 2000. Job satisfaction, comparison earning and gender. Labour 14, 473-502.

[47] Slattery, J.P., Selvarajan, T.T.R., 2005. Antecedents to temporary employee's turnover intention. Journal of Leadership and Organizational Studies, 12, 53-66.

[48] Souza-Poza, A., Souza-Poza, A., 2007. The effect of job satisfaction on labour turnover by gender: an analysis for Switzerland. The Journal of Socio-Economics, 36, 895-913.

[49] Spector, P.E., 1997. Job satisfaction: Application, assessment, causes, and consequences, Sage, London.

[50] Stier, H., Lewin-Epstein, N., 2003. Time to work: a comparative analysis of preferences for working hours. Work and Occupations, 30, 302326.

[51] Sweeney, P.D., McFarlin, D.B., 2004. Social comparisons and income satisfaction: a cross-national exanimation. Journal of Occupational and Organizational Psychology, $77,149-154$.

[52] Theodossiou, I.; Zangelidis, A., 2009. Career prospects and tenure-job satisfaction profiles: Evidence from panel data. The Journal of Socio-Economics, Elsevier, 38(4), 648657. 